\title{
DINAMIKA PENULARAN PENYAKIT DEMAM BERDARAH DENGUE (DBD) DI KECAMATAN PURWOKERTO SELATAN KABUPATEN BANYUMAS TAHUN 2015
}

\author{
Nur'Aini $^{1)}$, Aris Santjaka ${ }^{2)}$, Asep Tata Gunawan ${ }^{3)}$ \\ Jurusan Kesehatan Lingkungan, Politeknik Kesehatan Kemenkes Semarang, \\ Jl. Raya Baturaden KM 12 Purwokerto, Jawa Tengah, Indonesia
}

\begin{abstract}
Abstrak
Kasus DBD selalu menetap di Kecamatan Purwokerto Selatan selama lima tahun terakhir, pada tahun 2015 terdapat 72 kasus. Peningkatan kasus dan sebaran yang semakin meluas dapat digambarkan dengan dinamika penularan. Dinamika penularan digunakan untuk mengetahui riwayat sebaran penyakit, model sebaran dan determinan. Penelitian ini bertujuan untuk mengetahui dinamika penularan penyakit Demam Berdarah Dengue (DBD) di wilayah Kecamatan Puskesmas Purwokerto Selatan Tahun 2015. Jenis penelitian ini adalah penelitian observasional dengan pendekatan survey kualitatif berdasarkan catatan pasien tahun 2015. Pengumpulan data dengan wawancara dan pengukuran lingkungan fisik dan potensi penularan. Data kasus diolah dengan System Informasi Geografis (SIG). Analisa berdasarkan mapping wilayah, penggabungan fakta dengan determinannya dengan teknik overflow antara kejadian DBD dengan curah hujan. Deskripsi waktu kejadian tertinggi terjadi pada bulan April sebanyak 12 kasus (17\%), deskripsi tempat kejadian tertinggi di Kelurahan Teluk sebanyak 18 kasus (25\%) dan deskripsi orang kejadian tertinggi pada kelompok umur 6-55 tahun sebanyak 58 kasus (80\%) dan golongan jenis kelamin perempuan sebanyak 49 kasus (68\%). Model cluster sejumlah 12 cluster dengan 39 kasus, dan model sparated sejumlah 33 kasus. Dugaan determinan nilai CI (2\%), HI (4\%), BI (6\%) dan ABJ (96\%), serta hasil pengukuran suhu rata-rata $29^{\circ} \mathrm{C}$, Kelembaban $82 \%$, dan pencahayaan 66 lux serta data curah hujan sepanjang tahun 2015 sebesar 2231 mm/tahun dengan hari hujan 113 hari/tahun. Upaya pengendalian dengan kimiawi, PSN-DBD, manajemen lingkungan dan pengendalian terpadu Potensi penularan meliputi CI, HI, BI rendah dan ABJ 96\% sedangkan kasus tinggi, ada dugaan salah penulisan laporan, terjadi transovari, Saran upaya pengendalian DBD dengan melaksanakan PE semestinya 24 jam sesudah penegakan diagnosa kasus dan PSN rutin.
\end{abstract}

Kata kunci

: Dinamika penularan, Model, Determinan

\begin{abstract}
Dengue cases always settle in District South Purwokerto over the last five years, in 2015 there were 72 cases. Increased cases and widespread distribution can be described with the transmission dynamics. Transmission dynamics is used to determine the distribution of the disease history, models of distribution and determinants. This study aims to determine the dynamics of disease transmission Dengue Hemorrhagic Fever (DHF) in the District Health Center 2015 South Purwokerto.This study is an observational study the occurrence of dengue cases in District South Purwokerto based documentation / South Purwokerto health center patient records in 2015 so widely known and distribution models were analyzed qualitatively determinant. The highest cases occurred in April (17\%), in the Village of the Gulf (25\%) and are in the age group 6-55 years (80\%), male (26\%), women (54\%). Model cluster number of 12 clusters with 39 cases, and the model number 35 case. Supposition determinant separated CI value (2\%), HI (4\%), BI (6\%) and ABJ (96\%), and the temperature is on average 290C, humidity 82\%, and 66 lux lighting as well as data rainfall throughout the year 20152231 / year and 113hari rainy days / year. Efforts to control with chemical methods, PSN-DBD, environmental management and integrated control The researchers concluded that the transmission dynamics of dengue occur with cluster models with 39 cases, and the model separated with 35 cases. Allegations of writing, there transovari, adaptability of larvae Ae. aegypti. Suggestions dengue control efforts by the PSN-DBD and environmental management modification and manipulation of the environment as well as counseling activity
\end{abstract}

Keywords : $\quad$ Dynamics of transmission, Model, Determinant

\section{PENDAhuluan}

Demam Berdarah Dengue (DBD) merupakan penyakit akut, bersifat endemik tetapi secara periodik dapat mendatangkan kejadian luar biasa (KLB) bahkan epidemik. Kasus DBD

) Email : nuraini_pwt@yahoo.com

Email : arissantjaka@gmail.com

3) Email : aseptatagunawan@yahoo.co.id dilaporkan pertama kali di Manila pada tahun 1954 oleh Quintos dkk, kemudian penyakit ini menyebar ke seluruh Asia Tenggara diantaranya Vietnam (1960), Singapura (1962), Srilangka (1965) dan Myanmar (1968). Perkembangan 
penyakit ini di Asia dan dunia merupakan salah satu topik pembahasan di TAG APSED bulan Juli 2015 di Malaysia. Kasus baru DBD di dunia meningkat 30 kali dalam 50 tahun ini.

Penyakit DBD mulai dikenal di Indonesia sejak tahun 1968 di Surabaya Aedes aegypti merupakan vektor utama penyakit DBD di Indonesia dan Aedes albopictus sebagai vektor sekunder. Kepadatan vektor ini di lingkungan manusia menyebabkan meningkatnya probabilitas penularan virus dengue terhadap orang sehat.

Kejadian Luar Biasa (KLB) Demam Berdarah Dengue (DBD) sepanjang Januari 2016 lebih sedikit dibanding Januari 2015. Ini terlihat dari jumlah daerah yang terkena DBD, jumlah kasus dan jumlah kematian yang lebih kecil dibanding periode yang sama tahun yang lalu. Data Direktorat Pengendalian Penyakit Tular Vektor dan Zoonosis Kementrian Kesehatan menyebutkan hingga akhir Januari tahun 2016, kejadian luar biasa (KLB) penyakit DBD dilaporkan ditemukan di 9 kabupaten dan 2 kota dari 7 provinsi di Indonesia. (Tribunnews.com)

Kabupaten endemis DBD di Jawa tengah adalah Magelang, Jepara dan Kota Semarang. Ketiga daerah tersebut mempunyai tren penularan DBD yang terus naik setiap tahunnya. Kejadian DBD tersebar di Cilacap, Purworejo, Klaten, Boyolali, Karanganyar, Grobongan, Pati, Jepara, Tegal serta Kota Semarang. (Redaksi rakyat jateng).

Penyebaran penyakit DBD dipengaruhi oleh kepadatan vektor Aedes aegypti yang tersebar luas di daerah tropis maupun sub tropis. Kepadatan vektor Aedes aegypti dipengaruhi oleh beberapa determinan penting antara lain iklim (curah hujan, kelembaban, suhu), cakupan program Pemberantasan Sarang Nyamuk Demam Berdarah Dengue (PSN-DBD) dan perilaku masyarakat. Sebaran kasus penyakit DBD yang semakin meluas sebenarnya dapat dipertahankan dengan dinamika penularan. Dinamika penularan merupakan suatu upaya untuk mengetahui riwayat sebaran penyakit, determinan dan model sebaran. Jika diketahui dinamika penularan, maka petugas kesehatan dapat mengeliminir sebaran, membuat perencanaan pencegahan dan penanggulangan penyakit sehingga KLB dapat diminimalisir.

Kabupaten Banyumas terdapat 17 desa sebagai wilayah endemis. Angka kejadian DBD di Kabupaten Banyumas tahun 2010 mencapai 696 kasus, 2011 turun menjadi 201 kasus, 2012 turun lagi menjadi 200 kasus, 2013 melonjak lagi ke angka 543 kasus, 2014 turun menjadi 209 kasus dan di 2015 bertambah 23 kasus menjadi 231 kasus. Penyelidikan Epidemiologi telah dilakukan terhadap 49 kasus dan pengendalian vektor dengan dengan fogging telah dilakukan.
(Laporan Dinas Kesehatan Kabupaten Banyumas Tahun 2015).

Purwokerto Selatan merupakan salah satu kecamatan di Kabupaten Banyumas dengan kasus DBD tercatat pada tahun 2010 sebanyak 126 kasus dengan wialayah tertinggi Kelurahan Karangklesem dengan 28 kasus, kemudian turun pada tahun 2011 sebanyak 67 kasus dengan wilayah tertinggi di Kelurahan Tanjung dengan 25 kasus. Tahun 2012 kasus turun kembali menjadi 31 kasus dan wilayah tertinggi di Kelurahan Karangklesem dengan 9 kasus. Tahun 2013 mengalami kenaikan sebanyak 92 kasus dengan wilayah tertinggi di Kelurahan Karangpucung dengan 21 kasus, tetapi pada tahun 2014 angka kejadian kasus turun hingga menjadi 67 kasus dengan wilayah tertinggi di Kelurahan Karangklesem dengan 26 kasus dan terakhir pada tahun 2015 angka kejadian kasus meningkat menjadi 92 kasus dengan wilayah yang paling tinggi kembali di Kelurahan Karangklesem dengan 23 kasus. Tindakan pengendalian vektor telah dilakukan di Kecamatan Purwokerto Selatan seperti Pengendalian Sarang Nyamuk Demam Berdarah Dengue (PSN-DBD) dan kegiatan survey jentik nyamuk, namum ABJ pada tahun 2015 di Kecamatan Purwokerto Selatan masih 90,88\%.

\section{BAHAN DAN METODE}

Jenis penelitian ini adalah penelitian observasional, karena dalam penelitian ini tidak memberikan perlakuan terhadap subyek penelitian dengan pendekatan survei kualitatif yaitu memberikan gambaran mengenai dinamika penularan penyakit demam berdarah dengue (DBD) di Kecamatan Purwokerto Selatan Kabupaten Banyumas tahun 2015.

\section{III.HASIL DAN PEMBAHASAN}

Kondisi Geografis

Kecamatan Purwokerto Selatan termasuk wilayah Kabupaten Banyumas memiliki ketinggian 74 meter dari permukaan laut, luas wilayah 1375,31 $\mathrm{Ha}$ atau $13,75 \mathrm{Km}^{2}$. Rata-rata jumlah curah hujan sebesar $2231 \mathrm{~mm} /$ tahun.

Ketinggian tempat berpengaruh terhadap perkembangbiakan nyamuk, wiayah dengan ketinggian di atas di atas $\pm 1.000 \mathrm{~m} \mathrm{dpl}$, karena ketinggian tersebut suhu udara terlalu rendah sehingga tidak memungkinkan nyamuk berkembangbiak (Kemenkes, 2011, h.57)

Kecamatan Purwokerto Selatan dengan ketinggiaan 74 m.dpl secara topografi merupakan daerah dataran rendah yang sangat potensial untuk perkembangbiakan nyamuk Ae. aegypti karena ketinggian tempat kurang $1.000 \mathrm{~m}$ dpl. Bila ketinggian tempat di atas $1.000 \mathrm{~m}$ dpl maka suhu udara akan rendah, secara umum perubahan antara $5^{\circ} \mathrm{C}-6^{\circ} \mathrm{C}$ nyamuk tidak tahan hidup dan 
akan mengalami kesulitan beradaptasi. Adaptasi nyamuk terjadi pada kelembaban tinggi, sehingga begitu kelembaban rendah, nyamuk mengalami kekeringan, hal ini berdampak pada kematian populasi nyamuk akibat perubahan tingkat kelembaban ini atau terjadi migrasi untuk mencari habitat yang baru, sedangkan pertumbuhan nyamuk akan terhenti sama sekali pada suhu di bawah $10^{\circ} \mathrm{C}$ dan di atas $40^{\circ} \mathrm{C}$.

\section{Kondisi Demografi}

Penduduk di wilayah Kecamatan

Purwokerto Selatan Kabupaten Banyumas sampai dengan bulan Desember 2015 berjumlah 81.737 jiwa yang terdiri dari laki-laki 41.407 jiwa dan perempuan 40.330 jiwa. Kepadatan penduduk di Kecamatan Purwokerto Selatan sebesar $44.444 \mathrm{Jiwa} / \mathrm{Km}^{2}$ termasuk kategori sangat tinggi $\left(\left(>1.200\right.\right.$ jiwa $\left./ \mathrm{km}^{2}\right)$ seperti tabel berikut :

\begin{tabular}{|c|c|c|c|c|}
\hline Kelurahan & $\begin{array}{l}\text { Jumlah } \\
\text { Penduduk } \\
\text { (Jiwa) }\end{array}$ & $\begin{array}{c}\text { Luas } \\
\text { Wilayah } \\
\left(\mathrm{Km}^{2}\right) \\
\end{array}$ & $\begin{array}{c}\text { Kepadatan } \\
\text { Penduduk } \\
\left(\mathrm{Jiwa} / \mathrm{Km}^{2}\right)\end{array}$ & $\begin{array}{l}\text { Kate- } \\
\text { gori }\end{array}$ \\
\hline Tanjung & 10.568 & 1,48 & 7,141 & $\begin{array}{l}\text { Sangat } \\
\text { tinggi }\end{array}$ \\
\hline $\begin{array}{l}\text { Karang } \\
\text { Pucung }\end{array}$ & 13.270 & 1,59 & 8,346 & $\begin{array}{l}\text { Sangat } \\
\text { tinggi }\end{array}$ \\
\hline $\begin{array}{l}\text { Karang } \\
\text { Klesem }\end{array}$ & 14.395 & 3,02 & 4,767 & $\begin{array}{l}\text { Sangat } \\
\text { tinggi }\end{array}$ \\
\hline Teluk & 17.204 & 3,51 & 4,901 & $\begin{array}{l}\text { Sangat } \\
\text { tinggi }\end{array}$ \\
\hline Berkoh & 10.938 & 1,86 & 5,881 & $\begin{array}{l}\text { Sangat } \\
\text { tinggi }\end{array}$ \\
\hline $\begin{array}{l}\text { Purwokerto } \\
\text { Kidul }\end{array}$ & 7.306 & 1,11 & 6,582 & $\begin{array}{l}\text { Sangat } \\
\text { tinggi }\end{array}$ \\
\hline $\begin{array}{l}\text { Purwokerto } \\
\text { Kulon }\end{array}$ & 8.056 & 1,18 & 6,827 & $\begin{array}{l}\text { Sangat } \\
\text { tinggi }\end{array}$ \\
\hline Jumlah & 81.737 & 13,75 & 44,444 & $\begin{array}{l}\text { Sangat } \\
\text { tinggi }\end{array}$ \\
\hline
\end{tabular}

Kepadatan penduduk akan berpengaruh pada transmisi penularan penyakit DBD atau pemindahan virus dengue dari satu orang ke orang lain karena bertambahnya penduduk akan membuat mobilitas penduduk semakin padat sehingga kontak vektor dengan manusia sangat sering terjadi sekali.

\section{Deskripsi waktu terjadinya penularan kejadian} $D B D$

Kasus positif yang didapatkan saat penelitian di Kecamatan Purwokerto Selatan Kabupaten Banyumas sebanyak 72 kasus. Kejadian DBD tahun 2015 tertinggi pada bulan Aprill sebanyak 12 kasus (17\%) dan terendah pada bulan Oktober tidak ditemukan kasus (0\%) seperti yang terlihat pada gambar berikut :

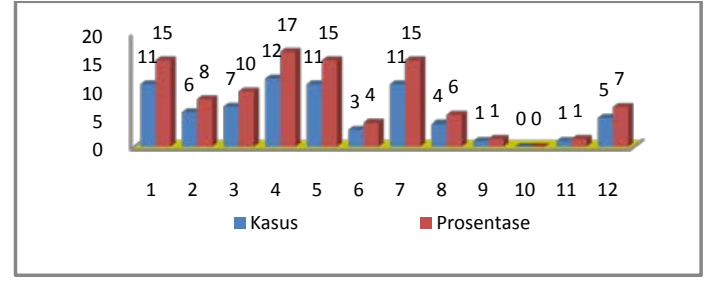

Kejadian DBD pada awal tahun cukup tinggi karena banyak terbentuk genangangenangan air yang terjadi pada musim penghujan sehingga menjadi habitat perkembangbiakan bagi jentik Ae. aegypti. Musim penghujan populasi Ae. aegypti akan meningkat, karena hujan berperan pada tersedianya siklus akuatik dalam siklus hidup nyamuk. Adanya hujan membuat telur-telur yang tadinya belum sempat menetas akan menetas ketika habitat perkembangannya mulai terisi air. Kondisi tersebut akan meningkatkan populasi nyamuk, sehingga dapat menyebabkan peningkatan kejadian DBD.

\section{Deskripsi tempat terjadinya penularan kejadian $D B D$}

Kasus positif yang didapatkan saat penelitian di Kecamatan Purwokerto Selatan Kabupaten Banyumas sebanyak 72 kasus. Kejadian DBD tahun 2015 tertinggi di Kelurahan Teluk sebanyak 18 kasus (25\%) dan terendah di Kelurahan Purwokerto Kulon sebanyak 1 kasus (1\%) seperti yang terlihat pada gambar berikut :

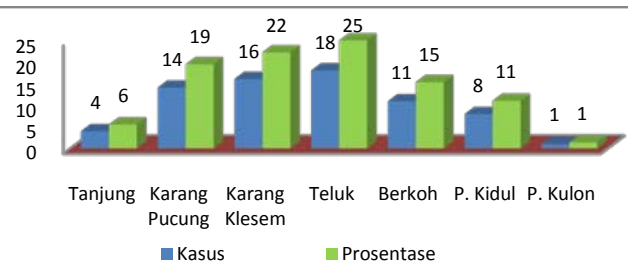

Hal ini dapat terjadi karena banyak pemukiman yang padat penduduk di Kelurahan Teluk dengan kondisi rumah yang saling berdekatan sehingga sangat berpotensi terjadi penularan penyakit melalui gigitan nyamuk $A e$. aegypti. Kelurahan Teluk merupakan wilayah yang strategis karena terdapat sarana umum yaitu

Terminal bus/angkutan Bulu Pitu Purwokerto. Penyebaran nyamuk secara pasif misal terbawa kendaraan dari berbagai wilayah dapat terjadi karena nyamuk betina dapat terbang rata-rata 50 meter dan ada kalanya sampai sejauh dua kilometer. Terminal merupakan salah satu tempat-tempat umum yang merupakan tempat potensial bagi penularan DBD karena terminal merupakan tempat berkumpulnya orang-orang yang datang dari berbagai wilayah sehingga 
kemungkinan terjadinya pertukaran beberapa tipe virus dengue cukup besar.

\section{Deskripsi penderita menurut umur dan seks pada penularan kejadian $D B D$}

Kasus positif yang didapatkan saat penelitian di Kecamatan Purwokerto Selatan, Kabupaten Banyumas didapatkan kejadian sebanyak 72 kasus. Kejadian DBD tahun 2015 tertinggi pada kelompok umur 6-55 tahun sebanyak 58 kasus (80\%) dan kejadian terendah pada kelompok umur 0-1 tahun sebanyak 1 kasus (1\%). Menurut golongan jenis kelamin, kejadian tertinggi pada golongan jenis kelamin perempuan sebanyak 49 kasus (68\%) dan kejadian terendah pada golongan jenis kelamin laki-laki sebanyak 23 kasus (32\%). Kejadian DBD menurut kelompok umur dan jenis kelamin dapat dilihat pada gambar berikut :

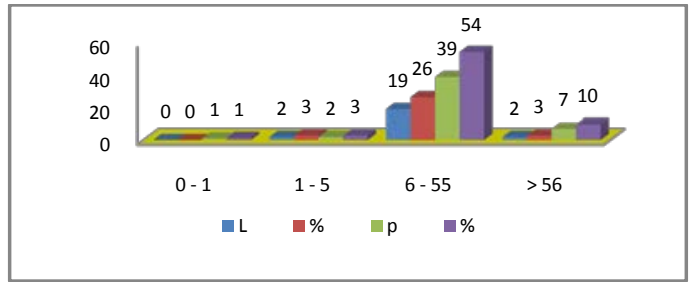

Penyakit Demam Berdarah Dengue (DBD) dapat menyerang semua golongan umur, namun sampai saat ini demam berdarah dengue lebih banyak menyerang anak-anak tetapi dalam dekade terakhir ini terlihat kecenderungan kenaikan proporsi kelompok dewasa. Meskipun penyakit demam berdarah dengue menyerang segala usia, beberapa penelitian menunjukkan bahwa anak-anak lebih rentan tertular salah satunya adalah karena faktor imunitas (kekebalan) yang relatif lebih rendah dibandingkan orang dewasa.

Kelompok umur 6-55 tahun tergolong dalam umur yang sangat berpengaruh terhadap tingkat keterpaparan besarnya resiko sehingga peluang terkena penyakit DBD lebih besar dibanding kelompok umur yang lain. Kelompok umur 6-55 tahun merupakan kelompok produktif dengan mobilitas yang tinggi seperti bekerja, sekolah, dan aktifitas lain. Berdasarkan

wawacara keberadaan penderita dua minggu sebelum sakit dari 72 penderita 30 kasus (42\%) berada di rumah dan 42 kasus (58\%) di luar rumah. Mobilitas yang tinggi dan didukung lancarnya hubungan transportasi membuat luas penyebaran virus dengue maupun nyamuk penularnya, sehingga dapat memunculkan penularan DBD yang disebut kasus import. Kelompok umur 0-1 tahun dengan kasus terendah karena pada kelompok umur ini bukan kelompok produktif sehingga aktifitas lebih banyak di rumah karena masih memiliki ketergantungan yang tinggi pada orang lain sehingga muncul penularan DBD yang disebut kasus indigenus.

Puncak aktivitas nyamuk Ae. aegypti antara pukul 09.00-10.00 dan 16.00-17.00. Waktu tersebut merupakan waktu beraktifitas kelompok jenis kelamin perempuan di tempat yang berdekatan dengan tempat penampungan air di dalam dan di sekitar rumah atau tempattempat umum. Tempat-tempat penampungan air di dalam atau di sekitar rumah untuk keperluan rumah tangga seperti ember, tempayan dan bak mandi/wc yang dimiliki masyarakat di Kecamatan Purwokerto Selatan terdapat di dalam rumah. Tempat penampungan air yang tidak melebihi jarak 500 meter dari rumah merupakan habitat perkembangbiakan utama bagi nyamuk Ae.aegypti.

\section{Radius penularan kejadian DBD di Kecamatan Purwokerto Selatan Kabupaten Banyumas \\ Kejadian DBD di Kecamatan Purwokerto Selatan Kabupaten Banyumas sebanyak 72 kasus dengan radius penularan \pm 100 meter dan $>100$ meter seperti terlihat pada tabel berikut :}

\begin{tabular}{|c|c|c|c|c|c|}
\hline \multirow{2}{*}{ Kelurahan } & \multicolumn{2}{|c|}{ Jumlah Kasus } & \multirow{2}{*}{$\begin{array}{c}\text { Jumlah } \\
\text { Kasus }\end{array}$} & \multicolumn{2}{|c|}{ Radius Penularan } \\
\hline & cluster & separated & & cluster & separated \\
\hline Tanjung & - & 4 & 4 & - & $>100 \mathrm{~m}$ \\
\hline Karang & 13 & 1 & 14 & $\pm 100 \mathrm{~m}$ & $>100 \mathrm{~m}$ \\
\hline Pucung & & & & & \\
\hline Karang & 12 & 4 & 16 & $\pm 100 \mathrm{~m}$ & $>100 \mathrm{~m}$ \\
\hline Klesem & & & & & \\
\hline Teluk & 4 & 14 & 18 & $\pm 100 \mathrm{~m}$ & $>100 \mathrm{~m}$ \\
\hline Berkoh & 7 & 4 & 11 & $\pm 100 \mathrm{~m}$ & $>100 \mathrm{~m}$ \\
\hline Purwokerto Kidul & 3 & 5 & 8 & $\pm 100 \mathrm{~m}$ & $>100 \mathrm{~m}$ \\
\hline Purwokerto Kulon & - & 1 & 1 & - & $>100 \mathrm{~m}$ \\
\hline Jumlah & 39 & 33 & 72 & & \\
\hline
\end{tabular}

Penyebaran nyamuk Ae. aegypti betina dewasa dipengaruhi oleh beberapa faktor termasuk ketersediaan tempat bertelur dan darah, tetapi tampaknya terbatas sampai jarak 100 meter dari lokasi kemunculan. Transportasi pasif dapat berlangsung melalui telur dan larva yang ada dalam penampungan (WHO, 2001).

Kejadian DBD di Kecamatan Purwokerto Selatan membentuk model sparated dan cluster.

Model ini disebabkan oleh jarak terbang nyamuk yang terbatas yaitu 100 meter karena adanya spiracle yang justru membatasi penyebaran dan jarak terbang nyamuk, sehingga pola penyebaran nyamuk cenderung berbentuk cluster (berkelompok). Jarak terbang bisa meluas kecuali nyamuk tersebut mengalami penyebaran secara pasif (misal terbawa kendaraan) sehingga berpindah ke daerah lain tanpa harus terbang dengan jarak yang jauh. Keadaan ini 
memberikan peluang untuk terjadi model penularan sparated.

\section{Model penularan penyakit DBD di Kecamatan Purwokerto Selatan Kabupaten Banyumas Model penularan \\ Model penularan separated terjadi apabila} tidak ada hubungan penularan satu sama lainnya dan kejadian kasus pertama dengan kasus yang lainnya berjarak $>100$ meter, sedangkan model penularan cluster terjadi apabila terdapat hubungan penularan satu sama lainnya dan kejadian kasus pertama dengan kasus lainnya berjarak \pm 100 meter (Cipto Aris P, 2010). Model penularan separated di Purwokerto Selatan terdapat 33 kasus. Berdasarkan waktu penegakan diagnosa penderita satu dengan penderita lain tidak ada hubungan penularan, jarak antara rumah penderita satu dengan penderita yang lain $>100$ meter dan berdasarkan wawancara tentang keberadaan responden dua minggu sebelum sakit, penderita berada di luar lingkungan tempat tinggalnya. Penderita mendapatkan virus dengue tidak dari lingkungan tempat tinggalnya melainkan dari tempat lain dan tidak menularkan orang di sekitarnya karena tidak adanya keberadaan vektor.

Model penularan cluster di Kecamatan Purwokerto Selatan sebanyak 12 cluster dengan 39 kasus. Kelompok cluster membentuk hubungan penularan antara penderita satu dengan penderita lainnya. Cluster Kelurahan Karang Pucung berdasarkan waktu penegakan diagnosa bahwa KP2 tertular oleh KP3 kemudian menularkan ke KP1, sedangkan KP5 menulari KP4, KP10 tertular oleh KP12 kemudian menularkan ke KP9 selanjutnya menular KP11. Cluster Kelurahan Karang Klesem berdasarkan waktu penegakan diagnosa bahwa KM6 menulari KM4 kemudian menulari KM 3 dan selanjutnya menulari KM 5. Kasus lain KM11 tertular oleh KM10. KM13 tertular oleh KM12 kemudian menulari KM14 selanjutnya menular KM15. Cluster Kelurahan Teluk berdasarkan waktu penegakan diagnosa bahwa TE7 tertular oleh TE9 menulari TE6 selanjutnya menulari TE8. Cluster Kelurahan Berkoh berdasarkan waktu

penegakan diagnosa bahwa BR4 menulari BR5 dan kasus lain BR11 tertular oleh BR8 menulari BR10 selanjutnya ke BR9. Cluster Kelurahan Purwokerto Kidul berdasarkan waktu penegakan diagnosa disimpulkan bahwa KL2 tertular oleh KL1 kemudian menulari KL3.

Model penularan cluster di Kecamatan Purwokerto Selatan berdasarkan pengamatan di lapangan jarak rumah antara kasus satu dengan kasus lainnya berjarak \pm 100 meter. Selain disebabkan jarak terbang nyamuk, clustering kejadian DBD cenderung mengikuti kepadatan penduduk sehingga menimbulkan problem kesehatan lingkungan, sebagaimana disampaikan oleh Umar Fahmi (2012) bahwa faktor kependudukan mempengaruhi proses penularan atau pemindahan penyakit dari satu orang ke orang lain. Kepadatan akan mempengaruhi produksi sampah atau limbah yang akhirnya berdampak buruk terhadap manusia itu sendiri. Lingkungan dengan sanitasi yang buruk biasanya terdapat barang-barang yang dipakai maupun tidak terpakai di sekitar rumah sehingga akan menambah tempat perkembangbiakan nyamuk apabila barang-barang tersebut menampung air. Pemukiman yang padat dengan gang-gang yang kecil sehingga kesempatan feeding habit sangat tinggi karena di lokasi cluster banyak manusia dan nyamuk Ae.aegypti menyukai darah manusia, mempunyai kebiasaan menggigit berulang kali (multiple biters) sehingga memudahkan proses penularan atau pemindahan virus dengue dari satu orang ke orang lain. Kondisi rumah kurang pencahayaan dan lembab serta ditemukan beberapa warga yang kondisi rumahnya tidak rapi dan mempunyai kebiasaan menggantungkan pakaian, ini memenuhi persyaratan lingkungan resting nyamuk Ae. aegypti, sedangkan resting nyamuk berdekatan dengan tempat perindukan nyamuk. Hasil penelitian di temukan positif jentik di tempat penampungan air di rumah KP9, KM3 dan TE1. Model penularan cluster sebagai indikator bahwa ada konsentrasi habitat vektor sehingga berpotensi lebih besar terjadi penularan setempat. Peta penyebaran kejadian DBD di Kecamatan Purwokerto Selatan dapat dilihat di bawah ini:

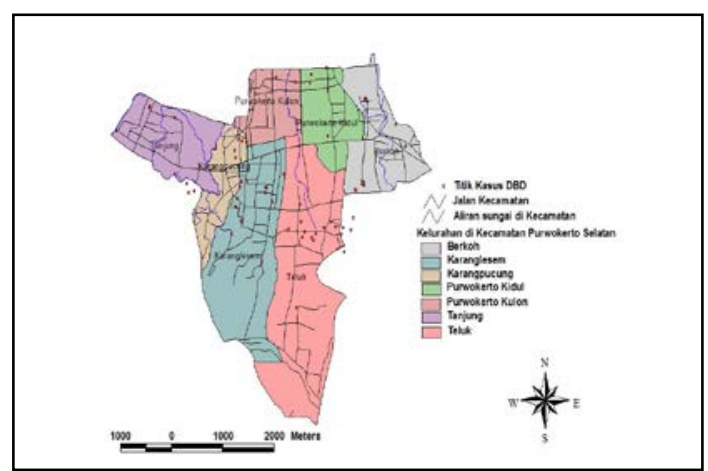

Hasil Penyelidikan Epidemiologi oleh petugas Puskesmas Purwokerto Selatan

Rentang waktu dilaksanakannya PE oleh petugas terlama yaitu 26 hari, rentang waktu tercepat 5 hari dengan rata-rata 14 hari, seperti pada tabel berikut :

\begin{tabular}{|c|c|c|c|c|}
\hline \multirow{2}{*}{$\begin{array}{c}\text { Kode } \\
\text { ID }\end{array}$} & \multicolumn{2}{|c|}{ Tanggal } & \multirow{2}{*}{$\begin{array}{c}\text { Rentang } \\
\text { Waktu } \\
\text { (Hari) }\end{array}$} & \multirow{2}{*}{$\begin{array}{l}\text { Penam } \\
\text { bahan } \\
\text { Kasus }\end{array}$} \\
\hline & $\begin{array}{c}\text { Penegakan } \\
\text { Diagnosa }\end{array}$ & $\begin{array}{c}\text { Pelaksanaan } \\
\text { PE }\end{array}$ & & \\
\hline TE 18 & 03-07-2015 & 18-07-2015 & 15 & 1 \\
\hline TE 8 & 23-07-2015 & 06-08-2015 & 13 & 3 \\
\hline KP 7 & 17-09-2015 & 05-10-2015 & 18 & 0 \\
\hline KM12 & $11-07-2015$ & 06-08-2015 & 26 & 4 \\
\hline
\end{tabular}




\begin{tabular}{lllrl} 
BR 1 & $17-08-2015$ & $04-09-2015$ & 17 & 1 \\
KP/AD & $1-07-2015$ & $06-07-2015$ & 5 & 0 \\
TE/NJ & $09-09-2015$ & $14-09-2015$ & 5 & 0 \\
KP/MT & $24-06-2015$ & $03-07-2015$ & 9 & 0 \\
\hline
\end{tabular}

Tujuan khusus PE untuk mengetahui adanya penderita dan tersangka DBD lainnya; mengetahui ada tidaknya jentik nyamuk penular DBD; menentukan jenis tindakan (penanggulangan fokus) yang akan dilakukan. Permenkes RI No: 1501/Menkes/Per/X/2010 tentang Jenis Penyakit Menular Tertentu yang Menimbulkan Wabah menyatakan bahwa PE desa atau kelurahan yang mengalami KLB dilakukan dalam waktu kurang dari 24 hari. Rentang waktu 14 hari merupakan waktu yang kurang cepat dalam memutus mata rantai penularan karena telah terjadi penambahan kasus. Penggalian informasi tentang kegiatan, mobilitas dan keberadaan penderita dua minggu sebelum sakit sampai 14 hari pelaksanaan PE menimbulkan Bias Recall karena penderita harus mengingat kegiatan yang lalu sehingga mempengaruhi jenis penularan apakah kasus indigenus atau kasus import. Hal ini mempengaruhi pengambilan keputusan jenis tindakan yang akan diambil. Sebaiknya PE dilakukan secepatnya setelah ditemukan penderita positif DBD dengan waktu kurang dari 1x24 jam sehingga perlu kerja sama yang aktif dari Puskesmas Purwokerto Selatan dan Rumah Sakit di wilayah Purwokerto dan sekitarnya serta peran masyarakat untuk ikut aktif kegiatan surveilans dalam mengenali secara dini tandatanda penyakit DBD.

Determinan dalam penularan kejadian DBD di Kecamatan Purwokerto Selatan Kabupaten Banyumas

Pengukuran suhu $\left({ }^{\circ} \mathrm{C}\right)$

Suhu udara di dalam rumah penderita DBD diperoleh suhu tertinggi di Kelurahan Tanjung sebesar $31^{\circ} \mathrm{C}$ dan suhu terendah di dua kelurahan yaitu Kelurahan Karang Pucung dan Kelurahan Karang Klesem sebesar $27^{\circ} \mathrm{C}$. Ratarata suhu di Purwokerto Selatan sebesar $29^{\circ} \mathrm{C}$.

Rata-rata suhu tiap kelurahan dapat dilihat pada gambar berikut :

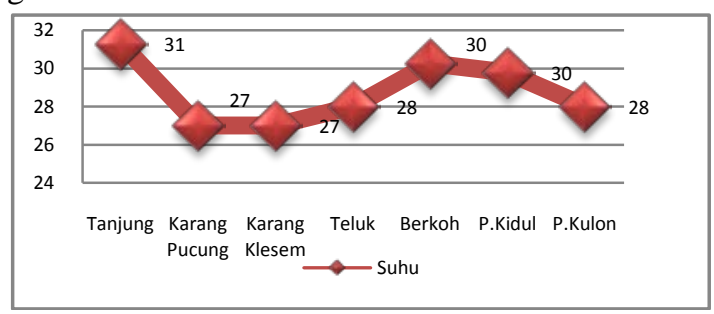

Nyamuk termasuk berdarah dingin, proses metabolisme dan siklus hidupnya tergantung pada suhu lingkungan. Suhu rata-rata optimum untuk perkembangan nyamuk adalah $25^{\circ} \mathrm{C}-27^{0} \mathrm{C}$, pertumbuhan nyamuk akan terhenti sama sekali kurang dari $10^{\circ} \mathrm{C}$ atau lebih dari $40^{\circ} \mathrm{C}$ (DIT.JEN.PP \& PL, 2007, h.8). Rata-rata suhu di Kecamatan Purwokerto Selatan sebesar $29^{\circ} \mathrm{C}$ sementara suhu optimum untuk pertumbuhan nyamuk yaitu $25^{\circ} \mathrm{C}-27^{\circ} \mathrm{C}$, sedangkan pertumbuhan nyamuk akan terhenti sama sekali kurang dari $10^{\circ} \mathrm{C}$ atau lebih dari $40^{\circ} \mathrm{C}$ maka suhu rata-rata di Kecamatan Purwokerto Selatan masih dalam batas suhu perkembangan dan pertumbuhan. Peran suhu sangat penting terkait dengan pernafasan dari nyamuk menggunakan trachea yang bermuara pada spiracle yang dibuka secara periodik hanya jika dibutuhkan dan menutupnya kembali jika dibutuhkan. Apabila suhu meningkat (kondisi udara kering) akan berdampak pada kelembaban rendah, kehilangan air akan terjadi dalam jumlah besar, dengan demikian mortalitas nyamuk akan jauh lebih banyak karena dehidrasi. Itulah sebabnya pengaruh suhu terhadap kepadatan nyamuk berkorelasi secara negatif artinya semakin naik suhu udara akan menurunkan densitas. Dampak suhu lainnya selain terhadap kelembaban dan peluang hidup nyamuk adalah terhadap kepadatan nyamuk karena nyamuk merupakan binatang yang tidak memiliki regulator pengatur kelembaban tubuh sehingga metabolisme dan siklus hidupnya tergantung pada suhu dan kelembaban lingkungan, dengan demikian pengaturan suhu dan kelembaban tubuh sangat tergantung pada lingkungannya.

Pengukuran kelembaban (\%)

Kelembaban di dalam rumah penderita DBD diperoleh kelembaban tertinggi di Kelurahan Karang Klesem sebesar 88\% dan kelembaban terendah di Kelurahan Tanjung sebesar 71\%. Rata-rata kelembaban di Kecamatan Purwokerto Selatan sebesar 82\%. Rata-rata kelembaban untuk tiap kelurahan dapat dilihat pada gambar berikut :

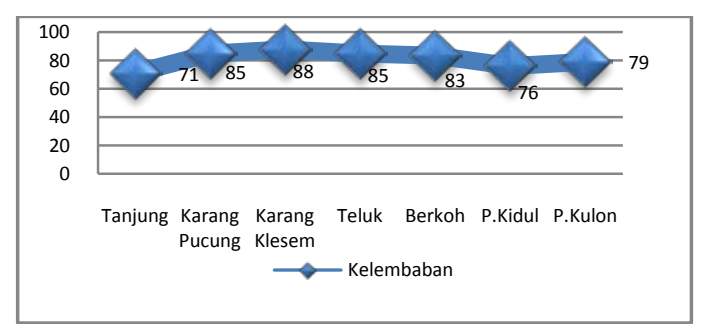

Rata-rata kelembaban di Kecamatan Purwokerto Selatan sebesar 82\%, hal ini menunjukkan bahwa kelembaban udara di Selatan lebih dari 60\% sesuai dengan teori bahwa nyamuk adalah hewan berdarah dingin, dan kehidupan nyamuk sangat tergantung pada lingkungan terutama kelembaban yang tinggi. Adaptasi nyamuk terjadi pada kelembaban tinggi sehingga umur nyamuk menjadi panjang dan cukup untuk siklus perkembangbiakan virus 
dengue dalam tubuh nyamuk. Jika kelembabannya rendah maka suhu lingkungan meningkat dan pencahayaan meningkat dengan demikian udara akan kering dan terjadi penguapan tinggi pada tubuh nyamuk karena nyamuk tidak mempunyai pembuluh darah tetapi mempunyai haemolymp yaitu cairan yang berfungsi menjaga kelembaban tubuh nyamuk sehingga jika terjadi ketidakseimbangan elektrolit saja akan mengalami dehidrasi dan hal ini berdampak pada kematian populasi nyamuk atau terjadi migrasi untuk mencari habitat yang baru. Spiracle tebuka saat nyamuk terbang maka kebutuhan oksigen tidak terpenuhi dan kehilangan air akan besar karena proses evaporasi. Hal ini lebih parah jika kondisi udara kering (suhu meningkat) yang berdampak pada kelembaban rendah, kehilangan air akan terjadi dalam jumlah besar dengan demikian mortalitas nyamuk akan jauh lebih banyak karena dehidrasi. Pengukuran pencahayaan (lux)

Pencahayaan di dalam rumah penderita DBD diperoleh pencahayaan tertinggi di Kelurahan Tanjung sebesar 75 lux dan pencahayaan terendah di Kelurahan Purwokerto Kidul sebesar 51 lux. Rata-rata di Kecamatan Purwokerto Selatan sebesar 66 lux. Hasil pengukuran pencahayaan untuk tiap kelurahan seperti yang terlihat pada gambar berikut:

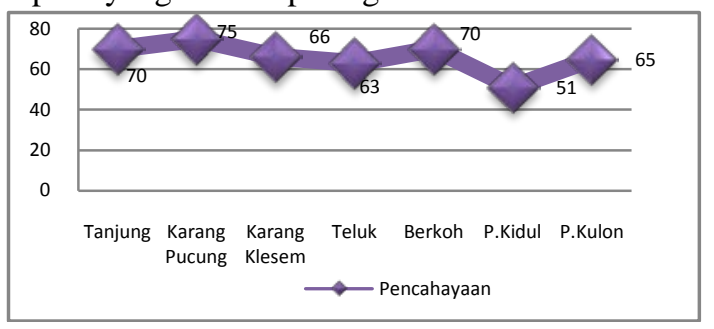

Nyamuk mempunyai kesukaan pada tempat yang redup dan range intensitas cahaya dikatakan redup antara 9 lux-325,7 lux (Saputra Bayu K, 2014).

Rata-rata pencahayan di Kecamatan Purwokerto Selatan sebesar 66 lux. Hal ini menunjukkan di Purwokerto Selatan memiliki intensitas cahaya yang redup. Intensitas cahaya redup karena kurangnya pencahayaan pada lingkungan pemukiman di Purwokerto Selatan yang padat penduduknya sehingga mengurangi masuknya sinar matahari pada pemukiman tersebut. Kurangnya sinar matahari menyebabkan temperatur menurun padahal konsentrasi uap air di udara di sekitar tempat tersebut tetap. Berdasarkan teori suhu dan kelembaban berbanding terbalik sehingga suhu rendah maka kelembaban menjadi tinggi. Hubungan pencahayaan, kelembaban dan suhu menyebabkan lingkungan yang padat penduduknya menjadi tempat yang baik bagi perkembangan hidup vektor DBD karena resting nyamuk Ae. aegypti adalah di tempat kelembaban cukup tinggi, teduh, suhu relatif rendah dan sedikit matahari. (Aris S, 2013). Kebutuhan kelembaban yang tinggi mempengaruhi nyamuk untuk mencari tempat yang lembab dan basah sebagai tempat hinggap atau beristirahat.

Curah hujan

Purwokerto Selatan memiliki jumlah curah hujan tahunan $2231 \mathrm{~mm}$ dengan hujan maksimum $83 \mathrm{~mm}$ dan jumlah hari hujan 113 hari. Dapat dirlihat pada gamabar berikut :

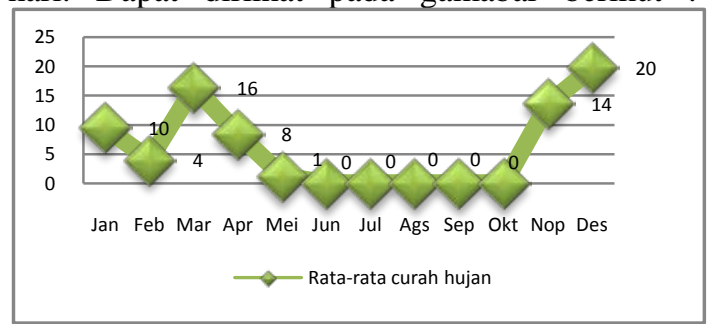

Curah hujan penting untuk kelangsungan hidup nyamuk Aedes aegypti. Curah hujan akan mempengaruhi naiknya kelembaban nisbi udara dan menambah jumlah tempat perkembangbiakan nyamuk di luar rumah. Curah hujan sebesar 2231mm/tahun merupakan intensitas yang tidak terlalu deras dan bila diselingi panas akan mengakibatkan tempat perindukan berupa genangan-genangan air dalam wadah/media sebagai breeding site bagi jentik Ae. aegypti bertambah dan dalam waktu 9-10 hari telur akan menjadi nyamuk, sedangkan curah hujan $>3.000 \mathrm{~mm} /$ tahun memiliki hujan

sangat deras memberikan pengaruh negatif artinya jika curah hujan semakin deras justru akan menghanyutkan larva yang ada, meskipun hal ini juga tergantung dari jenis larvanya, namun derasnya aliran mengangkat semua yang ada dalam breeding tersebut hanyut mengikuti aliran termasuk larva di dalamnya atau terjadi flushing, dengan demikian siklus hidup nyamuk akan terputus mata rantainya. Kepadatan larva mempengaruhi kepadatan nyamuk selanjutnya kepadatan nyamuk mempengaruhi pemindahan virus dengue dari manusia ke manusia lain. Hal ini sejalan dengan penelitian Sunaryo (2014) bahwa sebaran DBD di Kabupaten Banyumas lebih banyak pada area/lokasi dengan curah hujan sedang yaitu curah hujan 1.000-1.500 $\mathrm{mm} /$ tahun sedangkan pada curah hujan diatas $3.000 \mathrm{~mm} /$ tahun kasus ditemukan sedikit.

Pola kejadian DBD dan curah hujanpada tahun 2015 dapat dilihat pada gambar berikut : 


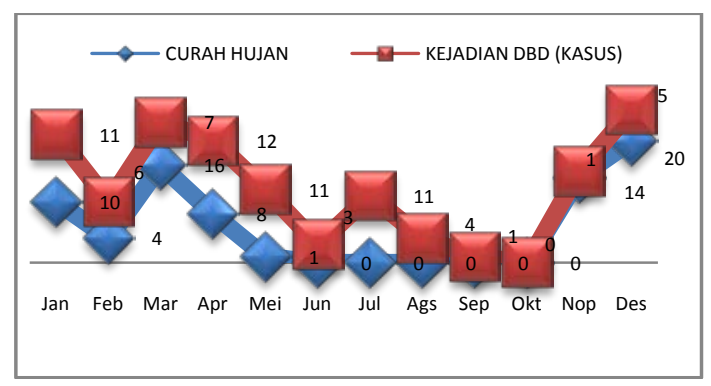

Pola kejadian DBD memperlihatkan pola yang berfluktuasi, ada kecenderungan kejadian DBD sedikit meningkat sedangkan curah hujan mengalami penurunan, dan pola kejadian DBD meningkat pada saat curah hujan tinggi. Kasus DBD tinggi terjadi pada bulan Januari-Mei dengan jumlah hari hujan 6-25 hari. Curah hujan yang cukup dengan jangka waktu lama akan meperbesar kesempatan nyamuk untuk berkembangbiak secara optimal sehingga terjadi peningkatan persebaran penyakit DBD. Sedangkan pada bulan Juni-Oktober terjadi kenaikan kasus padahal curah hujan $0 \mathrm{~mm}$ atau tidak ada hujan sama sekali, hal ini karena masih ada larva Ae. aegypti dalam breeding placenya misal di pot-pot bunga tempayan.

Nyamuk sangat tergantung pada kondisi lingkungan baik lingkungan fisik maupun lingkungan biologi, apabila kondisi lingkungan optimal maka perkembangan nyamuk akan cepat dengan demikian memperbesar kontak dengan manusia, dampaknya risiko penularan semakin besar. Lingkungan fisik tidak lepas dari kondisi iklim suatu tempat. Faktor iklim dapat meningkatkan atau mengurangi kepadatan vektor serta kontak manusia dengan vektor (Sukowati dalam Aris Santjaka, 2013)

Variabel iklim berupa faktor curah hujan akan menurunkan suhu dan karena peran curah hujan akan menambah kandungan uap air di udara, sehingga kelembaban akan tinggi, akibatnya usia nyamuk semakin panjang dan memungkinkan perkembangbiakan virus dengue dalam tubuh nyamuk, dengan demikian kejadian DBD akan meningkat berfluktuasi secara linier dengan curah hujan

Potensi penularan kejadian DBD di Kecamatan Purwokerto Selatan Kabupaten Banyumas

Determinan potensi penularan DBD dapat ditentukan melalui hasil perhitungan CI (2\%), HI (4\%), BI (6\%), dan ABJ (96\%). Hasil pengamatan saat penelitian ditemukan tempat penampungan air yag positif jentik yaitu di rumah KP3, KP9, KM3, dan TE1.

Determinan potensi penularan melalui hasil CI, HI, dan BI dan ABJ menunjukkan rendah untuk terjadi potensi penularan di
Kecamatan Purwokerto Selatan, sedangkan Purwokerto Selatan merupakan kecamatan dengan kasus tertinggi di Kabupaten Banyumas pada tahun 2015 dan nilai ABJ saat penelitian 96\%. Keadaan ini sangat bertolak belakang, seharusnya semakin tinggi nilai ABJ diharapkan jumlah kasus DBD menurun.

Beberapa asumsi untuk mendukung keadaan tersebut pertama penghitungan angka ABJ yang kurang tepat, kedua terjadi transovari dalam hal ini tidak perlu vektor nyamuk jumlah yang besar tetapi cukup beberapa nyamuk yang infektif yang menularkan virus dengue kepada keturunannya, ketiga berdasarkan penelitian Dian F (2014) ada kemampuan adaptasi larva Ae. aegypti ternyata rata-rata prosentase larva yang mampu bertahan hidup pada campuran air bersih dan air comberan (got) lebih tinggi dibandingkan pada media air bersih saja. Penelitian serupa oleh Kabul Bayu Saputra (2014) dan Ginanjar Ramadhani Putri (2014) di Perumahan Teluk Kecamatan Purwokerto bahwa telah terjadi kemampuan adaptasi larva Ae. aegypti pada air got termasuk selokan di Perumahan Teluk serta keempat kondisi lingkungan fisik yaitu suhu, kelembaban, pencahayan mendukung bagi perkembangan dan pertumbuhan nyamuk.

Upaya penanggulangan penularan penyakit DBD di Kecamatan Purwokerto Selatan Kabupaten Banyumas.

Upaya penanggulangan penyakit DBD telah dilaksanakan dengan beberapa metode yaitu secara kimiawi, biologi, Pemberantasan Sarang Nyamuk Demam Berdarah Dengue

(PSN-DBD) dan manajemen lingkungan serta pengendalian vektor terpadu.

Upaya pencegahan dan pengendalian penyakit DBD merupakan tanggungjawab bersama antara pemerintah baik lintas sektor maupun lintas program dan masyarakat termasuk swasta. Masyarakat dapat ikut berperan dalam upaya-upaya pencegahan dan pengendalian penyakit DBD, sebagai contoh peran masyarakat dalam kegiatan surveilans dalam mengenali secara dini tanda-tanda penyakit DBD yang menimpa salah satu keluarga atau tetangga mereka dan segera memeriksakan diri ke fasilitas pelayanan kesehatan sehingga dapat dilakukan penegakkan diagnosa secara dini dan diberikan pertolongan dan pengobatan dini, dalam pengendalian untuk memutus mata rantai penularan, masyarakat dapat berperan secara aktif dalam pemantauan jentik berkala dan kegiatan PSN. Meningkatkan pengetahuan masyarakat melalui penyuluhan bahwa PSN lebih efektif mengurangi penyebaran DBD 
daripada fogging yang hanya membunuh nyamuk dewasanya.

Upaya pengendalian dengan manajemen lingkungan di Purwokerto Selatan dapat ditingkatkan dengan manipulasi dan modifikasi lingkungan berupa penataan perbaikan perilaku hidup bersih dan sehat (PHBS), penataan ruangan yang baik, ventilasi yang cukup serta menghindari penyimpanan barang seperti gantungan baju yang berpotensi menjadi tempat istirahat nyamuk yaitu tempat gelap dan lembab.

\section{IV.KESIMPULAN}

Berdasarkan penelitian di Kecamatan Purwokerto Selatan diperoleh data 72 penderita DBD di , sebagai berikut:

1. Deskripsi waktu, kejadian tertinggi pada bulan April sebanyak 12 kasus (17\%) dan kejadian terendah pada bulan Oktober sebanyak 0 kasus (0\%).

2. Deskripsi tempat kejadian tertinggi di Kelurahan Teluk sebanyak 18 kasus (25\%) dan kejadian terendah di Kelurahan Purwokerto Kulon sebanyak 1 kasus (1\%).

3. Deskripsi penderita menurut umur, kejadian tertinggi pada kelompok umur 6-55 tahun sebanyak 58 kasus (80\%) dan kejadian terendah pada kelompok umur 0-1 tahun sebanyak 1 kasus (1\%) sedangkan kejadian menurut seks, kejadian tertinggi pada golongan jenis kelamin perempuan sebanyak 49 kasus (68\%) dan kejadian terendah pada golongan jenis kelamin laki-laki sebanyak 23 kasus (32\%).

4. Radius penularan kejadian DBD berjarak jarak $\pm 100 \mathrm{~m}$ sehingga terbentuk penularan cluster dan $>100 \mathrm{~m}$ terbentuk penularan sparated.

5. Model penularan DBD terdapat 12 cluster dengan 39 kasus, dan sparated dengan 33 kasus.

6. Pengukuran kondisi lingkungan fisik didapatkan rata-rata suhu $29^{\circ} \mathrm{C}$, kelembaban 82\% dan pencahayaan 66 lux serta data curah hujan $2231 \mathrm{~mm} /$ tahun dengan jumlah hari hujan 113 hari/tahun.

7. Pengukuran determinan potensi penularan didapatkan hasil CI sebesar 2\%, HI sebesar 4\%, BI sebesar 6\% dan ABJ sebesar 96\%.

8. Upaya pengendalian yang dilakukan melalui pengendalian secara kimiawi, pengendalian secara biologi, pengendalian dengan pemberantasan sarang nyamuk demam berdarah dengue (PSN-DBD), pengendalian manajemen lingkungan, serta pengendalian terpadu.

\section{DAFTAR PUSTAKA}

Achmadi, U.F, 2008, Manajemen Penyakit Berbasis Wilayah, Jakarta: Universitas Indonesia

Aris Cipto Purnomo, Dinamika Penularan Penyakit Demam Berdarah Dengue di Indonesia,Skripsi, Jakarta: Universitas Indonesia

Aris Santjaka, 2013, Pendekatan Model Kausalitas, Malaria, cetakan pertama, Yogyakarta: Nuha Medika

Buletin Jendela Epidemiologi, 2010, Demam Berdarah Dengue, Jakarta: Pusat Data Dan Survailans Epidemiologi Kemenkes R.I Vol 2

Bunga Rampai Catatan Kegiatan 2015, Penelitian dan Terapannya di Kesehatan Masyarakat, Jakarta: Badan Penelitian Dan Pengembangan Kesehatan

Cecep Dani Sucipto, 2011, Vektor Penyakit Tropis,Cetakan Pertama, Yogyakarta: Gosyen Publishing

Departemen Kesehatan R.I, Direktorat Jenderal Pengendalian Penyakit dan Penyahatan Lingkungan (DIT.JEN.PP\&PL), 1992, Petunjuk Teknis Pemberantasan Nyamuk Penular Penyakit Demam Berdarah Dengue, Edisi Tahun 1994, Jakarta: DIT.JEN.PP\&PL.

Petunjuk Teknis Penyelidikan Epidemiologi, Penanggulangan Seperlunya dan Penyemprotan Massal dalam Pemberantasan Penyakit Demam Berdarah Dengue, Edisi Tahun 1994, Jakarta: DIT.JEN.PP\&PL

Pemberantasan Penyakit Demam Berdarah Dengue di Indonesia, Jakarta: DIT.JEN.PP\&PL

Ginanjar Rahmadhani P, Eksplorasi Spesies Larva Nyamuk di Selokan Kecamatan Purwokerto Selatan Kabupaten Banyumas (Studi Kasus pada Perumahan Teluk) Purwokerto : Politeknik Kemenkes Semarang Jurusan Kesehatan Lingkungan Purwokerto

Jusniar A, Athena A, 2014, Model Prediksi Kejadian Demam Berdarah Dengue 
(DBD) Berdasarkan Faktor Iklim di Kota Bogor Jawa Barat, at http://ejournal.litbang.depkes.go.id/indexs .php/BPK/article/view/3563/3601/, diakses tanggal 28 Januari 2016 pukul $14.50 \mathrm{WIB}$

Kabul Bayu S, 2014, Eksplorasi Spesies Nyamuk di Selokan Kecamatan Purwokerto Selatan Kabupaten Banyumas (Studi Kasus pada Perumahan Teluk) Tahun 2014, Purwokerto : Politeknik Kemenkes Semarang Jurusan Kesehatan Lingkungan Purwokerto

Kementerian Kesehatan R.I, Direktorat Jenderal Pengendalian Penyakit dan Penyehatan Lingkungan(DIT.JEN.PP\&PL), Modul Pengendalian Demam Berdarah Dengue, Jakarta: DIT.JEN.PP\&PL

Kementerian Kesehatan RI, 2015, Demam Berdarah Biasanya Mulai Meningkat di Januari at http://www.depkes.go.id/article/print/150 $\underline{11700003}$, di akses tanggal 25 Juli 2016 pukul $10.00 \mathrm{WIB}$

Kementerian Kesehatan RI, 2015, Wilayah KLB DBD Ada di 11 Propinsi, at http://www.depkes.go.id/article/print/160 30700001/wilayah-klb-dbd, di akses tanggal 25 Juli 2016 pukul 10.00 WIB

Kementerian Kesehatan RI, 2016, Penjelasan Kementrian Kesehatan Tentang Kejadian Luar Biasa DBD, at www.tribunners/2016/02/05/penjelasan, di akses tanggal 25 Juli 2016

Nova P, Anggun Paramitha D, 2012, Distribusi Vektor Demam Berdarah Dengue Daerah Perkotaan Dan Perdesaan di Kabupaten Banjarnegara, http://ejournal.litbang.depkes.go.id/indexs .php/BPK/article/view/3287/3281, diakses tanggal 17 Januari 2016 pukul 13.00 WIB Rakyat Jateng, 2016, Jateng Darurat DBD, Virus Zika Mengancam, at http://rakyajateng.com/berita-jatengdarurat-viruszikamengancam.html, diakses tanggal 1 Mei 2016

Ringga Fidayanto, Hari Susanto, Agus Yohanan, Ririh Yudastuti, 2013, Model Pengendalian Demam Berdarah Dengue, Journal Kesehatan Masyarakat Nasional, Vol 7, No. 17,
Sari, Cut I, N, 2005, Pengaruh Lingkungan terhadap Perkembangan Penyakit Malaria Dan Demam Berdarah, at http://www.rudyct.com/PPS702ipb/09145/cut irsanya ns.pdf, diakses tanggal 13 Januari 2016 pukul 20.55 WIB

Soegeng S, 2008, Demam Berdarah Dengue, Edisi 2, Surabaya: Airlangga University Press

Suhendro, dkk, Demam Berdarah Dengue, Buku Ajar Penyakit Dalam, Fakultas Kedokteran UI, Jakarta: Universitas Indonesia

Sunaryo, Bina I, Dewi PN, 2014, Distribusi Spasial Demam Berdarah Dengue (DBD) Di Kabupaten Banyumas Provinsi Jawa Tengah, at http://ejournal.litbang.depkes.go.id/index. php/blb/article/view/3534 diakses tanggal 28 Januari 2016 pukul 14.50 WIB

Teguh W, Kajian Manajemen Lingkungan terhadap Kejadian Demam Beradah Dengue di Kota Purwokerto Jawa Tengah, Thesis, Semarang: Universitas Diponegoro

M. Nur Huda, Laporan Tribun Jawa Tengah, 2016, at http://jateng.tribunnews.com/2016/02/19/, diakses tanggal 28 Juli 2016 pukul 15.00 WIB

World Health Organization, 2001, Pencegahan dan Pengendalian Dengue \& DBD, Panduan Lengkap, Jakarta: EGC

Zainudin, 2003, Analisis Spasial Kejadian Penyakit Demam Berdarah Dengue di (DBD) di Kota Bekasi Tahun 2003, Thesis pascasarjana Ilmu Kesehatan Masyakat, Jakarta: Uniersitas Indonesia 


\title{
HUBUNGAN SANITASI MAKANAN DENGAN KEBERADAANTELUR CACING PADA KUBIS YANG DIGUNAKAN SEBAGAI LALAPAN DI WARUNG MAKAN KAWASAN KOTA BANJARNEGARA TAHUN 2016
}

\author{
Setyawati Budi Utami ${ }^{1)}$, Budi Triyantoro ${ }^{2)}$, Nur Hilal ${ }^{3)}$ \\ Jurusan Kesehatan Lingkungan, Politeknik Kesehatan Kemenkes Semarang, \\ Jl. Raya Baturaden KM 12 Purwokerto, Indonesia
}

\begin{abstract}
Abstrak
Angka kontaminasi Soil Transmitted Helminths (STH) pada sayuran masih cukup tinggi. Proses pengolahan dan pencucian sayuran mentah yang siap makan yang kurang baik mempermudah transmisi telur cacing ke manusia. Tujuan penelitian ini adalah mengetahui hubungan sanitasi makanan dengan keberadaan telur cacing pada kubis yang digunakan sebagai lalapan di warung makan kawasan Kota Banjarnegara.Jenis penelitian ini merupakan penelitian observasional dengan analisis deskriptif dengan pendekatan Cross sectional. Pengambilan sampel penelitian dilakukan satu kali yaitu sebanyak 24 sampel dari 24 warung makan. Pemeriksaan telur cacing menggunakan metode tak langsung dengan teknik sedimentasi. Pada sampel kubis yang ditemukan adanya telur Soil Transmitted Helminths (STH), ditentukaan jenis telurnya. Hasil penelitian menunjukkan bahwa 95,8\% (23 sampel) terkontaminasi oleh telur Soil Transmitted Helminths (STH). Jenis telur cacing yang ditemukan antara lain telur cacing Tambang, telur cacing Ascaris lumbricoides, telur cacing Trichuris trichiura dan telur cacing Oxyuris vermicularis.Kesimpulan dari penelitian ini adalah bahwa variabel higiene penjamah makanan dan variabel praktik pencucian kubis 100\% berkategori buruk, sedangkan variabel persediaan air bersih 33,3\% berkategori baik, 66,7\% berkategori buruk dan untuk variabel kondisi warung makan terhadap sumber pencemar 16,7\% memenuhi syarat, 83,3\% tidak memenuhi syarat kesehatan.
\end{abstract}

Kata kunci : lalapan kubis; telur cacing usus

\section{Abstract}

[Title: The corelation of food sanitaton with worm's egg in raw cabbage using as side dish in restaurants around Banjarnegara in 2016]The problem caused by this worm still found today. The number of Soil Transmitted Helminths (STH) contamination in vegetable also high. The bad process to prepare and wash the vegetable make the worm's egg transmission to human easier. This research aim to find out if there are correlation between food sanitation with the worm's egg existence in raw cabbage using as side dish in the restaurants around Banjarnegara. This research is an observational research using descriptive analysis with Cross sectional approach. The sampling done once, taken 24 samples from 24 restaurants. Worm's egg examination using indirect method with sedimentation technique. In cabbage which contain Soil Transmitted Helminth, the variety be identified. The result show that 95,8\% (23 samples) contaminated by Soil Transmitted Helminths (STH) egg. The eggs identified as hook worm's egg, Ascaris lumbricoides's egg, Trichuris trichiura's egg and Oxyuris vermicularis's egg. The conclusion of this research is that food hygiene variable and cabbage washing process variable 100\% categorized poor, while $33,3 \%$ of water categorized good, $66,7 \%$ categorized poor. For the restaurant's sanitation $16,7 \%$ in good condition, $83,3 \%$ is poor.

Key Word: raw cabbage using as side dish, Soil Transmitted Helminths

\section{Pendahuluan}

Penyakit kecacingan merupakan salah satu masalah kesehatan masyarakat yang memiliki angka kejadian relatif tinggi di Indonesia tetapi belum mendapatkan perhatian serius dari pemerintah dalam upaya penanggulangannya. Alasan utama bahwa penyakit kecacingan tidak akan menyebabkan kematian seketika merupakan salah satu alasan terabaikannya perhatian pada penyakit menular ini. Pada akhirnya hingga saat ini penyakit kecacingan menjadi salah satu penyakit menular yang kurang

1) Email : setyawati_budiutami@yahoo.com

2) Email : inung.nh@gmail.com

3) Email : mutshabira@yahoo.co.id diperhatikan (neglected disease) oleh pemerintah di Indonesia (Litbangkes, 2008).

Berbagai faktor yang mendukung tingginya angka kesakitan karena infeksi cacing perut di Indonesia adalah letak geografis Indonesia di daerah tropis yang mempunyai iklim yang panas tetapi lembab, memungkinkan cacing perut dapat berkembang biak dengan baik. Banyak penduduk Indonesia yang masih berpendidikan rendah, sehingga pengetahuan tentang cara untuk hidup bersih dan sehat dengan menjaga kebersihan perseorangan dan kebersihan makanan dan minuman 
belum dipahami dengan baik. Banyak keluarga yang tidak memiliki jamban keluarga, sehingga mereka membuang kotoran di sembarang tempat missal di kebun atau selokan terbuka sehingga menimbulkan pencemaran lingkungan hidup oleh kotoran manusia yang bisa saja mengandung telur cacing atau larva (stadium infektif) cacing perut.Faktor lain yang juga berpengaruh adalah kebiasaan masyarakat mengkonsumsi sayuran mentah yang dimakan tanpa dimasak terlebih dahulu yang biasa disebut lalapan. Sayuran mentah mempunyai risiko besar untuk terkontaminasi mikroorganisme atau jasad renik misalnya telur cacing.

Sayuran mentah yang telah terkontaminasi telur cacing atau larva ini, banyak disajikan sebagai lalapan di warung-warung makan di Kota Banjarnegara. Keterbatasan persediaan air di kebanyakan warung makan memperkuat kemungkinan terjadinya kecacingan bagi konsumennya. Kondisi warung makan yang sangat minim persediaan air membuat pencucian sayuran dilakukan dengan air yang tidak mengalir, dan air pencucinya dipakai untuk beberapa kali pencucian sayuran. Meskipun air masih nampak bening dan bersih, tetapi tidak menutup kemungkinan bahwa air tersebut mengandung telur cacing yang terlepas dari sayuran yang dicuci, sehingga telur cacing yang sudah terlepas tadi dapat menempel kembali pada sayuran yang dicuci berikutnya. Telur cacing yang menempel di sayuran tadi ikut dihidangkan sebagai lalapan, dan masuk ke perut manusia yang mengkonsumsi lalapan tersebut. Akibatnya orang tersebut terinfeksi telur cacing/ larva dan timbulah penyakit kecacingan.

Kubis merupakan sayuran yang cukup digemari untuk dijadikan lalapan. Terbukti kubis sangat mudah ditemukan di warung-warung makan. Kubis dapat ditanam pada berbagai jenis tanah. Daun kubis berposisi duduk sehingga kontak langsung dengan tanah. Keadaan ini memungkinkan telur cacing akan mudah menempel pada daun kubis yang berada dekat dengan lokasi BAB terutama pada bagian krop terluar dan ujung bagian kubis.

Penelitian Maemunah (1993) menyatakan proporsi kontaminasi telur cacing pada sayuran kubis, dan kubis di Bandungan dan Kopeng Kota Semarang sebesar 71,67\%. Kontaminasi telur cacing pada sayuran sendiri sudah banyak dilaporkan, khususnya pada kubis karena memiliki permukaan daun yang sangat berlekuk sehingga telur cacing yang menempel pada daun kubis sulit untuk dibersihkan, terutama jika proses pencucian tidak dilakukan dengan baik.Dari data statistik sekitar 90\% penyakit yaitu pada manusia mempunyai keterkaitan dengan makanan sebanyak 25\% penyebaran penyakit melalui makanan, diakibatkan oleh pekerja yang menderita infeksi dan higiene perorangan buruk (Purnawijayanti, 2001:41). Demikian juga menurut Febria Agustina (2009) menyatakan bahwa sumber kontaminasi makanan yang paling besar pengaruhnya adalah pekerja/ penjamah makanan.

Berdasarkan latar belakang tersebut peneliti tertarik untuk melakukan penelitian tentang hubungan antara sanitasi makanan dengan keberadaan telur cacing pada kubis yang digunakan sebagai lalapan di warung makan kawasan Kota Banjarnegara.

Hipotesis penelitian ini adalah ada hubungan antara variabel higiene penjamah makanan , variabel praktik pencucian kubis, variabel persediaan air bersih dan variabel kondisi warung makan terhadap sumber pencemar dengan keberadaan telur cacing pada kubis yang digunakan sebagai lalapan di warung makan kawasan Kota Banjarnegara, sedangkan tujuan penelitian ini adalah untuk mengetahui adanya hubungan sanitasi makanan meliputi variabel higiene penjamah makanan, praktik pencucian kubis, persediaan air bersih dan kondisi warung makan terhadap sumber pencemar dengan keberadaan telur cacing pada kubis yang digunakan sebagai lalapan di warung makan kawasan Kota Banjarnegara.

\section{Bahan dan Metode}

Penelitian ini dilakukan di Laboratorium UPT Puskesmas Banjarnegara 1. Jenis penelitian ini adalah merupakan penelitian observasional dengan analisis deskriptif dan menggunakan pendekatan Cross sectional yaitu peneliti melakukan observasi atau pengukuran variabel pada satu saat yang telah dilaksanakan pada bulaan Juni 2016. Pengambilan sampel dengan menggunakan teknik simple random sampling.Sampel dalam penelitian ini adalah kubis yang berasal dari 24 warung makan di kawasan Kota Banjarnegara. Kubis yang diteliti adalah kubis yang siap disajikan untuk konsumen. Selain kubis bahan yang digunakan larutan $\mathrm{NaOH}$ $0,2 \%$. Alat yang digunakan adalah tabung sedimentasi, pipet tetes, centrifuge, rak tabung, mikroskop, obyek glass, ember, dan pinset. Prosedur kerja dimulai dengan merendam kubis dalam larutan $\mathrm{NaOH} \quad 0,2 \%$ selama 30 menit. Kemudian kubis diangkat dan air sisa rendaman dimasukkan ke dalam tabung sedimentasi kemudian diamkan selama 1 jam. Setelah itu, ambil endapan sebanyak 10-15 ml lalu dicentrifuge dengan kecepan 1500 rpm selama 5 menit. Kemudian lakukan pemeriksaan mikroskopis dengan perbesaran 10-40 kali. Identifikasi Soil Transmitted Helminthsdilakukan dengan menyesuaikan bentuk STH yang ditemukan dengan bentuk pada atlas parasitologi. Data disajikan dalam bentuk tabel distribusi frekuensi.

\section{Hasil dan Pembahasan}

Berdasarkan hasil penelitian tentang hubungan sanitasi makanan dengan keberadaan telur cacing yang digunakan pada lalapan kubis di warung 
makan kawasan Kota Banjarnegara didapatkan hasil sebagai berikut:

\section{a. Higiene penjamah makanan}

Tabel 1. Distribusi Frekuensi Higiene Pejamah Makanan

\begin{tabular}{cccc}
\hline $\mathrm{N}$ & $\begin{array}{c}\text { Higiene } \\
\text { Penjamah } \\
\text { Makanan }\end{array}$ & Frekuensi & $\begin{array}{c}\text { Prosentase } \\
(\%)\end{array}$ \\
\hline 1. & Buruk & 24 & 100 \\
2. & Baik & 0 & 0 \\
\hline & Jumlah & 24 & 100 \\
\hline
\end{tabular}

Hasil penelitian ini dari 24 responden $100 \%$ tidak memakai sarung tangan selama pengolahan makanan, $25 \%$ yang melakukan cuci tangan pakai sabun sebelum mengolah makanan, 16,7\% yang menggunakan penjepit/ sendok/ garpu saat mengambil makanan sehingga akumulasi skor untuk variabel higiene penjamah makanan masuk kategori buruk.

\section{b. Praktik Pencucian Kubis}

Tabel 2. Distribusi Frekuensi Praktik PencucianKubis

\begin{tabular}{lccc}
\hline No & $\begin{array}{c}\text { Praktik } \\
\text { Pencucian }\end{array}$ & Frekuensi & $\begin{array}{c}\text { Prosentase } \\
(\%)\end{array}$ \\
\hline 1. & Buruk & 24 & 100 \\
2. & Baik & 0 & 0 \\
\hline \multicolumn{2}{c}{ Jumlah } & 24 & 100 \\
\hline
\end{tabular}

Praktik pencucian kubis pada penelitian ini 100\% responden berkatagori buruk karena tidak satupun yang mencuci kubis dalam lembar per lembar tetapi masih dalam keadaan bulatan utuh meskipun ada beberapa yang mencucinya di bawah air mengalir.

\section{c. Persediaan Air Bersih}

Tabel 3. Distribusi Frekuensi Persediaan Air Bersih

\begin{tabular}{cccc}
\hline No & $\begin{array}{c}\text { Persediaan } \\
\text { Air Bersih }\end{array}$ & Frekuensi & $\begin{array}{c}\text { Prosentase } \\
(\%)\end{array}$ \\
\hline 1. & Baik & 8 & 33,3 \\
2. & Buruk & 16 & 66,7 \\
\hline & Jumlah & 24 & 100,0
\end{tabular}

Hasil penelitian untuk persediaan air bersih pada penelitian ini hanya 33,3\% yang baik yaitu secara fisik memenuhi syarat, secara pemenuhan kebutuhan air juga tercukupi dan sarana mencuci berupa air mengalir.

\section{d. Kondisi Warung Makan terhadap Sumber Pencemar}

Tabel 4. Distribusi Frekuensi Kondisi Warung Makan terhadap Sumber Pencemar

\begin{tabular}{llcc}
\hline No & $\begin{array}{c}\text { Kondisi Sanitasi } \\
\text { Warung }\end{array}$ & Frekueni & $\begin{array}{c}\text { Prosentase } \\
(\%)\end{array}$ \\
\hline 1. & $\begin{array}{l}\text { Memenuhi Syarat } \\
\text { 2. }\end{array}$ & 4 & 16,7 \\
& $\begin{array}{l}\text { Tidak Memenuhi } \\
\text { Syarat }\end{array}$ & 20 & 83,3 \\
\hline
\end{tabular}

\begin{tabular}{l}
\hline Jumlah 24 100,0 \\
\hline Penelitian ini diperoleh hasil dari 24 responden \\
responden 29,17\% jarak dari sumber pencemar \\
seperti bak pengumpul sampah, WC, pembuangan \\
limbah kurang dari 100m. Untuk tempat sampah \\
seluruh responden memiliki tetapi 33,3\% responden \\
tempat sampahnya tidak kedap air, 75\% responden \\
tempat sampahnya tidak tertutup, 33,3\% responden \\
tidak terdapat kantong plastik pada tempat \\
sampahnya. Keberadaan lalat terlihat di 25\% \\
responden. Sementara itu untuk hewan peliharaan \\
dari 24 responden 100\% tidak terlihat memeliharanya \\
di warung makan.
\end{tabular}

\section{e. Keberadaan Telur Cacing pada Lalapan Kubis}

Tabel 5. Distribusi Telur Cacing pada Lalapan Kubis

\begin{tabular}{llcc}
\hline No & $\begin{array}{l}\text { Keberadaan } \\
\text { telur cacing }\end{array}$ & Frekuensi & Prosentase (\%) \\
\hline 1. & Ada & 23 & 95,8 \\
2. & Tidak & 1 & 4,2 \\
\hline & Jumlah & 24 & 100,0
\end{tabular}

Berdasarkan hasil penelitian dari 24 sampel lalapan kubis dari warung makan seputar kawasan Kota Banjarnegara didapatkan 23 sampel (95,8\%) positif telur cacing. Distribusi telur cacing yang ditemukan di 23 sampel tersebut adalah 6 sampel (26,8\%) positif telur cacing Tambang dan Ascaris lumbricoides, 5 sampel $(21,7 \%)$ positif telur cacing Tambang, 4 sampel $(17,4 \%)$ positif telur Ascaris lumbricoides, 2 sampel (8,7\%) positif telur Trichuris trichiura, 2 sampel $(8,7 \%)$ positif telur Oxyuris vermicularis, 1 sampel (4,3\%) positif telur cacing Tambang, Ascaris lumbricoides dan Trichuris trichiura, 1 sampel (4,3\%) positif telur cacing Tambang, Oxyuris vermicularis dan Ascaris lumbricoides, 1 sampel (4,3\%) positif telur Ascaris lumbricoides dan Trichuris trichiura dan 1 sampel (4,3\%) lagi positif telur cacing Tambang dan Trichuris trichiura. Telur Ascaris lumbrocoides adalah yang paling banyak ditemukan. Dominasi telur Ascaris sp pada penelitian ini disebabkan oleh sifat dari telur Ascaris sp yang tahan terhadap desinfektan kimiawi serta terhadap rendaman sementara di dalam berbagai bahan kimia seperti $\mathrm{NaOH}$ yang digunakan pada penelitian ini. Selain itu, telur dapat hidup berbulan-bulan di dalam air selokan dan tinja.

Untuk mengetahui hubungan antar variabel dengan keberadaan telur cacing pada lalapan kubis dapat dilihat pada tabel-tabel berikut ini: 
Tabel 6. Hubungan Higiene Penjamah Makanan dengan Keberadaan Telur Cacing pada Lalapan Kubis

\begin{tabular}{llccc}
\hline & \multicolumn{4}{c}{ Keberadaan Telur } \\
No & $\begin{array}{l}\text { Higiene } \\
\text { Penjamah } \\
\text { Makanan }\end{array}$ & \multicolumn{2}{c}{ Lalapan Kubis } & Total \\
& & Ada & Tidak & \\
\hline 1. & Buruk & 23 & 1 & 24 \\
2. & Baik & 0 & 0 & 0 \\
\hline & Jumlah & 23 & 1 & 24 \\
\hline
\end{tabular}

Tabel 7. Hubungan Praktik Pencucian Kubis dengan keberadaan Telur Cacing pada Lalapan Kubis

\begin{tabular}{|c|c|c|c|c|}
\hline \multirow[t]{2}{*}{ No } & \multirow[t]{2}{*}{$\begin{array}{l}\text { Praktik } \\
\text { Pencucian } \\
\text { Kubis }\end{array}$} & $\begin{array}{l}\text { Kebera } \\
\text { Cacing } \\
\text { Lalapa }\end{array}$ & $\begin{array}{l}\text { Telur } \\
\text { pada } \\
\text { bis }\end{array}$ & \multirow[t]{2}{*}{ Total } \\
\hline & & \multicolumn{2}{|c|}{$\begin{array}{l}\text { Lalapan Kubis } \\
\text { Ada } \quad \text { Tidak }\end{array}$} & \\
\hline 1. & Buruk & 23 & 1 & 24 \\
\hline 2. & Baik & 0 & 0 & 0 \\
\hline & Jumlah & 23 & 1 & 24 \\
\hline
\end{tabular}

Tabel 8. Hubungan Persediaan Air Bersih dengan Keberadaan Telur Cacing pada Lalapan Kubis

\begin{tabular}{ccccc}
\hline \multirow{2}{*}{ No } & $\begin{array}{c}\text { Persediaan } \\
\text { Air Bersih }\end{array}$ & \multicolumn{2}{c}{$\begin{array}{c}\text { Keberadaan Telur } \\
\text { Cacing pada }\end{array}$} & \multirow{2}{*}{ Totala } \\
\cline { 3 - 4 } & & Ada & Tidak & \\
\hline 1. & Buruk & 16 & 0 & 16 \\
2. & Baik & 7 & 1 & 8 \\
\hline & Jumlah & 23 & 1 & 24 \\
\hline
\end{tabular}

Tabel 9. Hubungan Kondisi Warung Makan terhadap Sumber Pencemar dengan Keberadaan Telur Cacing pada Lalapan Kubis

\begin{tabular}{|c|c|c|c|c|}
\hline \multirow[t]{2}{*}{ No } & \multirow{2}{*}{$\begin{array}{c}\text { Kondisi } \\
\text { Warung } \\
\text { Makan } \\
\text { terhadap } \\
\text { Sumber } \\
\text { Pencemar } \\
\end{array}$} & \multicolumn{2}{|c|}{$\begin{array}{c}\text { Keberadaan } \\
\text { Telur Cacing } \\
\text { pada Lalapan } \\
\text { Kubis } \\
\end{array}$} & \multirow[t]{2}{*}{ Total } \\
\hline & & Ada & Tidak & \\
\hline 1. & Buruk & 20 & 0 & 20 \\
\hline 2. & Baik & 3 & 1 & 4 \\
\hline & Jumlah & 23 & 1 & 24 \\
\hline
\end{tabular}

Hasil analisis bivariat pada penelitian ini untuk hubungan antara variabel higiene penjamah makanan dengan keberadaan telur cacing pada lalapan kubis tidak dapat dilakukakan uji chi square karena nilainya konstan, demikian juga untuk hubungan antara variabel praktik pencucian kubis dengan keberadaan telur cacing. Hasil uji chi square untuk hubungan antara variabel persediaan air bersih dengan keberadaan telur cacing dinyatakan tidak mempunyai hubungan yang signifikan ditunjukkan dengan $p$-value sebesar 0,333 yang berarti $>0,05$ $(0,333>0,05)$, demikian juga untuk variabel kondisi warung makan dengan keberadaan telur cacing pada lalapan kubis tidak mempunyai hubungan yang signifikan dengan didapatkan $p$-value sebesar 0,167 $(0,167>0,05)$.

Dikemukakan oleh Siti Fatonah (2005:11) dalam penelitiannya sentuhan tangan merupakan penyebab yang paling umum terjadinya pencemaran makanan. Mikroorganisme yang melekat pada tangan akan berpindah ke dalam makanan dan berkembang biak dalam makanan, terutama dalam makanan jadi atau siap santap. Siti Fathonah (2005:15) juga mengungkapkan bahwa kuku tangan sering menjadi sumber kontaminasi atau mengakibatkan kontaminasi silang. Kontaminasi silang dapat terjadi selama makanan berada dalam tahap persiapan, pengolahan, pemasakan maupun penyajian. Higiene penjamah makanan yang buruk dapat menyebabkan kontaminasi mikrobiologis pada makanan karena penjamah makanan merupakan sumber potensial dalam perpindahan mikroorganisme. Pada penelitian dari 24 responden tidak satupun (100\%) yang menggunakan sarung tangan pada saat menjamah makanan, 6 responden (25\%) yang melakukan cuci tangan pakai sabun sebelum mengolah makanan, 4 responden (16,7\%) menggunakan penjepit/ sendok/ garpu saat mengambil makanan.Dari data statistik sekitar 90\% penyakit yaitu pada manusia mempunyai keterkaitan dengan makanan sebanyak 25\% penyebaran penyakit melalui makanan, diakibatkan oleh pekerja yang menderita infeksi dan higiene perorangan buruk (Purnawijayanti, 2001:41). Demikian juga menurut Febria Agustina (2009) menyatakan bahwa sumber kontaminasi makanan yang paling besar pengaruhnya adalah pekerja.

Bagian terpenting dari pengelolaan sayuran mentah agar siap dikonsumsi adalah pencucian. Pencucian dapat mengurangi atau bahkan menambah jasad renik (dalam hal ini telur cacing) tergantung pada cara pencucian, jenis sayuran dan mutu air pencuci. Sayuran daun mempunyai permukaan yang berlekuk dari pada sayuran buah, sehingga telur cacing yang menempel pada sayuran daun lebih sulit dibersihkan. Tetapi, hal tersebut dapat diatasi dengan mencuci lembar demi lembar sayuran, kemudian dicelupkan sebentar ke dalam air panas merendam sayuran dengan menggunakan larutan garam terlebih dahulu yang kemudian dilanjutkan dengan mencuci kembali sayuran, dan dengan menggunakan air mengalir sehingga STH yang mungkin melekat dapat terbuang bersama aliran air tersebut. (Muyassaroh, 2006). Sementara pada penelitian ini tidak satupun responden yang mencuci kubis per lembar melainkan mencuci dalam keadaan bulatan utuh meskipun ada yang mencucinya di air yang mengalir. 
Air yang digunakan pada proses pengolahan hendaknya air bersih yang memenuhi persyaratan Permenkes RI No.416/MENKES/PER/IX/1990. Penyakit-penyakit bawaan makanan pada dasarnya tidak dapat dipisahkan dari penyakit -penyakit bawaan air. Makanan dan air merupakan suatu media yang dapat menyebabkan penyakit (WHO:2005). Pada penelitian ini secara fisik air yang digunakan 100\% memenuhi persyaratan yaitu tidak berwarna, tidak berbau dan tidak berasa. Seluruh responden pada penelitian ini diketahui menggunakan air PDAM untuk semua keperluan pengelolaan makanannya. Untuk persyaratan fisik air yaitu tidak berwarna, tidak berbau dan tidak berasa seluruh responden dinyatakan memenuhi syarat. Dengan demikian peneliti mengasumsikan bahwa tidak berhubungannya persediaan air bersih dengan keberadaan telur cacing pada lalapan kubis dikarenakan air yang digunakan berasal dari PDAM yang sudah melalui proses desinfeksi terlebih dahulu yang berfungsi membunuh mikroorganisme yang ada di dalamnya termasuk telur cacing, sehingga meskipun hasil pemeriksaan laboratorium dari 24 sampel lalapan kubis 23 (95,8\%) sampel dinyatakan positif telur cacing, persediaan air bersih yang berasal dari PDAM tersebut tidak ikut berkontribusi mengkontaminasi telur cacing pada lalapan kubis tersebut.

Kondisi warung makan terhadap sumber pencemar tidak mempunyai hubungan yang signifikan dengan keberadaan telur cacing pada kubis yang digunakan sebagai lalapan di warung makan seputar Kota Banjarnegara. Hal ini dapat ditunjukkan dari hasil uji statistik Chi-square antara variabel kondisi warung makan terhadap sumber pencemar dengan keberadaan telur cacing pada lalapan kubis yang diperoleh $p$-value sebesar 0,167 lebih besar dari 0,05 (0,167>0,05).Febria Agustina, dkk (2009) menyatakan menjajakan makanan dalam keadaan terbuka dapat meningkatkan risiko tercemarnya makanan oleh lingkungan, baik melalui udara, debu, bahkan serangga yang dapat saja menjadi agent pembawa mikroorganisme patogen termasuk telur cacing dari tinja manusia. Berdasarkan BPOM (2003:9) tempat-tempat yang paling disukai lalat untuk berkembang biak adalah sampah, selokan, dan kotoran manusia. Lalat-lalat tersebut merupakan sumber mikroorganisme patogen dan secara mekanik mengantarkan mikroorganisme dari satu tempat ke tempat lain dengan cara hinggap di atas permukaan yang kotor, kemudian berpindah ke makanan (Arisman, 2009:9). Sehingga meskipun dinyatakan tidak mempunyai hubungan yang signifikan dengan keberadaan telur cacing tetapi kondisi sanitasi warung makan tetap harus diperhatikan. Upaya sanitasi warung dilakukan dengan cara mengatur faktor faktor lingkungan warung yang berkaitan dengan rantai perpindahan penyakit sehingga mencegah terjadinya penyakit yang disebabkan oleh makanan akan dapat lebih optimal.

Penelitian ini dapat menjelaskan kepada kita bahwa kubis sangat berpotensial untuk penularan penyakit yang disebabkan oleh STH. Maka dalam hal ini sangat diperlukan upaya pencegahan. Untuk menghindari agar STH yang terdapat pada sayuran kubis tidak masuk ke tubuh, maka tindakan preventif yang dapat dilakukan yaitu pencucian kubis dengan air mengalir karena dapat menghilangkan STH yang menempel pada daun kubis sebanyak $94 \%$.

\section{Kesimpulan}

Simpulan dari penelitian ini adalah sanitasi makanan yang meliputi higiene penjamah makanan, praktik pencucian kubis, persediaan air bersih dan kondisi warung makan terhadap sumber pencemar di warung makan yang menyajikan lalapan kubis di kawasan Kota Banjarnegara dinyatakan masih belum memenuhi persyaratan ditunjukkan dengan sampel kubis yang diambil dari kubis yang siap disajikan sebagai lalapan sebesar 95,8\% mengandung telur cacing. Keadaan yang demikian ini saharusnya segera disikapi oleh Dinas Kesehatan untuk melakukan pembinaan terhadap pedagang agar memperhatikan prinsip pengelolaan makanan dan menggalakkan program pencegahan dan pengobatan penyakit cacingan bagi masyarakat. Bagi pedagang sebaiknya melakukan perilaku hidup bersih dan sehat misalnya menjaga kebersihan tangan dengan membiasakan mencuci tangan sebelum memasak, menggunakan sarung tangan/ penjepit/ sendok/ garpu dalam mengambil makanan dan praktik-praktik higiene sanitasi makanan lainnya seperti mencuci sayuran yang akan digunakan sebagai lalapan lembar demi lembar di air yang mengalir atau merendam sayuran di larutan garam dan air hangat kemudian dibilas dengan air mengalir.Bagi peneliti selanjutnya perlu ada penelitian lebih lanjut dengan jenis variabel yang berbeda seperti variabel asal kubis, variabel penggunaan pupuk organik dan variabel lainnya, atau dengan sampel penelitian yang berbeda seperti selada, kemangi, mentimun dan lain-lain untuk mengetahui faktor lain yang berhubungan dengan keberadaan telur cacing pada lalapan yang ada di warung-warung makan.

\section{Ucapan Terima Kasih}

Puji syukur kehadirat Alloh SWT yang telah memberikan rahmat dan karuniaNya, sehingga penulis dapat menyelesaikan skripsi ini dengan judul Hubungan Sanitasi Makanan dengan Keberadaan Telur Cacing pada Kubis yang Digunakan sebagai Lalapan di Warung Makan Kawasan Kota Banjarnegara. Dalam penyelesaian skripsi ini penulis banyak mendapat bantuan baik materiil maupun moril dari berbagai pihak, untuk itu penulis mengucapkan terima kasih kepada Bapak Sugiyanto, S.Pd., M.App.Sc., selaku Direktur Politeknik 
Kesehatan Kemenkes Semarang, Bapak Asep Tata Gunawan, SKM., M.Kes., selaku Ketua Jurusan Kesehatan Lingkungan Politeknik Kesehatan Kemenkes Semarang, Bapak Hari Rudijanto I.W., ST., M.Kes., selaku Ketua Program Studi Kesehatan Lingkungan Politeknik Kesehatan Kemenkes Semarang, Bapak Budi Triyantoro, ST., M.Kes., selaku pembimbing I, Bapak Nur Hilal, SKM., M.Kes., selaku pembimbing II, Semua Dosen dan Karyawan Poltekkes Kemenkes Semarang Jurusan Kesehatan Lingkungan Purwokerto Prodi DIV Kesehatan Lingkungan, Orangtua, suami, keluarga dan teman-teman yang tidak dapat disebut satu per satu. Mudah-mudahan skripsi ini bermanfaat bagi kita semua.

\section{DAFTAR PUSTAKA}

Agus Syahrurachman, 1994, Buku Ajar Mikrobiologi Kedokteran, Jakarta: Bina Putra Aksara.

Ali

Khomsan, 2005, Pencucian Sayuran.http://www.google.com._Diakses tanggal

16 Juli 2016.

Alviyatun, 2012. Hubungan antara kebiasaan mencuci sayuran dengan adanya telur cacing pada air bekas pencuci sayuran di warung lesehan kota Yogyakarta 2012. Skripsi S1, UNY

Arisman, 2009, Keracunan Makanan: Buku Ajar Ilmu Gizi. Jakarta: EGC.

Balai Pengawas Obat dan Makanan, 2003, Higiene dan Sanitasi Pengolahan

Chairini Tri Cahyaningsih, Haripurnomo Kushadiwijaya,Abu Tholib,2009, Hubungan Higiene Sanitasi dan Perilaku Penjamah Makanan dengan Kualitas Bakteriologis Peralatan Makan di Warung makan. Berita Kedokteran Masyarakat: Balai Teknologi Kesehatan Lingkungan, Bagian Ilmu Kesehatan Masyarakat, Bagian Mikrobiologi, Volume25, Nomor 4, Desember 2009, hlm.180-188.

C.Totok. Surtrisno, 2006, Teknologi Penyediaan Air Bersih. Jakarta: Rineka Cipta

Febria Agustina, dkk, 2009, Higiene dan Sanitasi Pada Pedagang Jajanan Tradisional di Lingkungan Sekolah Dasar di Kelurahan Demang Lebar Daun Palembang Tahun 2009. JurnalPenelitian Hygiene Sanitasi (online).http://uppm.fkm.unsri.ac.id/, diakses 30 Januari 2016.
Kepmenkes RI No. 1096/MENKES/PER/VI/2011 tentang Higiene Sanitasi Jasa Boga. http://www.depkes.go.id/download/SK1098. 03.pdf,diakses pada 3 Februari 2016

Litbangkes, 2008. Laporan Hasil Riset Kesehatan Dasar (RISKESDAS). Nasional 2007. Depkes RI.

Marlina, 2007. Hubungan Kondisi Sanitasi dan Praktik Penjamah Makanan dengan Kandungan Echerichia coli Pada Tempe Penyet di Warung makan Tembalang Semarang 2007Skripsi S1, Universitas Diponegoro.

Purnawijayanti, H., 2001, Sanitasi, Higiene dan Keselamatan Kerja dalam Pengolahan Makanan, Yogyakarta: Kanisius.

Siti Fathonah, 2005. Higiene dan Sanitasi Makanan, Semarang: UNNES Press.

Siti Muyassaroh, 2006, Pengaruh Frekuensi Pencucian pada Daun Kubis (Brassica oleracea var Capitata) terhadap Jumlah Telur Cacing Usus (Nematoda Intestinalis). FKM UNIMUS. Semarang

Soedarto, Helmintologi Kedokteran. Penerbit Buku Kedokteran, EGC. Jakarta.1990 